\title{
Snakeweed: Poisonous properties, livestock losses, and management considerations
}

\author{
KIRK C. MCDANIEL AND TIMOTHY T. ROSS
}

Authors are Professors, Dept. of Animal and Range Sciences, New Mexico State Univ., Las Cruces, N.M. 88003.

\begin{abstract}
Snakeweeds (broom, Gutierrezia sarothrae (Pursh) Britt \& Rusby); and threadleaf, G. microcephala (DC.) Gray) fall into that class of poisonous weeds that seldom cause direct livestock losses because they are highly unpalatable and animals rarely consume large quantities of plant material. However, when snakeweed becomes dominant on rangeland and retards growth of desirable forage, then indirectly it becomes a serious hazard to animal health. Confined and rangeland feeding trials conducted at New Mexico State University with cattle and sheep have failed to elicit reproductive failure with elevated snakeweed dosages. Snakeweed was shown to impair certain reproductive functions such as pituitary responsiveness to luteinizing hormone, and caused mild hepato-renal toxicity. Under rangeland conditions, livestock grazing in areas dominated by snakeweed reportedly have more serious problems, such as abortion. A commonality between confined feeding trials and rangeland grazing trials is that in the presence of snakeweed, animals typically display symptoms associated with a low-plane of nutrition such as lack of gain, emaciation, and occasional death. To reduce snakeweed dominance and improve range condition, management interventions such as herbicide or fire control may be necessary. Complicating the decision regarding snakeweed control is the uncertainty about treatment life and whether this relatively short-lived perennial weed might be eliminated by natural causes. Knowing the snakeweed population pattern in a given area greatly enhances management decisions.
\end{abstract}

Key Words: Poisonous plant, range weed, livestock grazing, broom snakeweed (Gutierrezia sarothrae (Pursh) Britt \& Rusby), threadleaf snakeweed (Gutierrezia microcephala (DC.) Gray)

Broom (Gutierrezia sarothrae (Pursh) Britt \& Rusby) and threadleaf (G. microcephala (DC.) Gray) snakeweed are shortlived perennial shrubs within the Asteraceae family. Because they are similar in appearance and often occupy the same ecological niches, they are commonly referred together in the literature as simply, snakeweed (Sterling et al. 1999). Both species are indigenous to North America with broom snakeweed distributed from Mexico to southern Canada, while threadleaf snakeweed is found

This paper was supported by the New Mexico Agr. Exp. Sta., Las Cruces, NM 88003 and was funded in part by a special grant for Broom Snakeweed Research.

Author to whom correspondence should be addressed. Dept. of Animal and Range Sciences, New Mexico State University, Las Cruces, NM 88003. Phone: (505) 646-1191; Fax: (505) 646-5441; E-mail: kmcdanie@nmsu.edu.

Manuscript accepted 2 Sept. 01.
Resumen

"Snakeweeds" (broom, Gutierrezia sarothrae (Pursh) Britt \& Rusby) y "Threadleaf" (G. microcephala (DC.) Gray) caen dentro de la categoría de las malezas tóxicas que raramente causan perdidas directas de ganado porque ellas no le gustan al ganado y raramente los animales consumen grandes cantidades de material vegetal de estas plantas. Sin embargo, cuando el "Snakeweed" llega a ser dominante en el pastizal y retarda el crecimiento de especies deseables, entonces se convierte en un serio peligro para la salud animal. Estudios de alimentación en confinamiento y en pastizal realizados en la Universidad Estatal de Nuevo Mexico con ovinos y bovinos han fallado en lograr un fracaso reproductivo con dosis elevadas de "Snakeweed". "Snakeweed" mostró deteriorar ciertas funciones reproductivas tales como la respuesta de la pituitaria a la hormona luteinizante y causo una toxicidad hepato-renal ligera. Bajo condiciones de pastizal, el ganado apacentando en áreas dominadas por "Snakeweed" tiene problemas mucho mas serios como abortos. Algo común entre los ensayos en confinamiento y los de apacentamiento en pastizales es que en la presencia de "Snakeweed" los animales típicamente muestran síntomas asociados con un plano nutricional bajo, tal como la falta de ganancia de peso, demacración y muerte ocasional. Para reducir la dominancia del "Snakeweed" y mejorar la condición del pastizal, es necesario realizar practicas de manejo tal como el uso de herbicidas o fuego para controlar esta planta. Algo que complica la decisión respecto al control del "Snakeweed" es la incertidumbre acerca de la duración del tratamiento y si esta especie perenne de vida relativamente corta pudiera ser eliminada por causas naturales. Conociendo el patrón de la población de "Snakeweed" de una área dada mejora grandemente las decisiones de manejo.

mainly in the Chihuanhuan and Sonoran deserts of Mexico and the southwestern United States.

Snakeweeds contain a rich mixture of alkaloids, flavonoids, saponins, terpenes, and other compounds that are often causal agents in various plants that poison rangeland livestock. These substances also render snakeweed highly unpalatable so that when given a choice animals usually will not eat the foliage. Bite into a snakeweed leaf and you'll quickly appreciate from the harsh burning taste why other common names, such as fireweed and turpentine weed are so appropriate. Snakeweeds are rarely eaten by any large wild or domestic animal (Smith et al. 1991) and with the exception of a few specialist foliage feeding insects, such as the red-kneed grasshopper (Hesperotettix viridis [Thomas]) (Thompson et al. 1995, Foster et al. 1981, Richman 
and Thompson 1995) snakeweeds are rarely damaged by grazing.

Pieper (1989) reviewed literature reporting snakeweed in herbivore diets and found it usually absent but occasionally as much as 3 to $10 \%$ of grazed diets in cattle, horses, sheep, goats, mule deer, jack rabbits, and pronghorn antelope. When snakeweed is grazed by livestock it is most likely because it is the predominant green plant among other dormant or scarce species. Cattle, sheep, and horses are reportedly killed by ingesting 10 to $20 \%$ of an animals body weight with snakeweed (Kingsbury 1964), but problems with reproduction and abortion are more commonly reported (Dollahite and Anthony 1957, Smith and FloresRodriguez 1989).

While snakeweed poisoning problems can not be discounted, the literature suggests that it is the plants competitive nature that causes major economic damage to livestock producers. Under dense snakeweed stands losses from diminished forage and livestock production usually far outweighs it's toxic properties. In this paper we discuss some recent findings from research pertaining to snakeweed toxicology and management. We have placed special emphasis on research we have been involved in at New Mexico State University ${ }^{1}$.

\section{Toxicity Problems}

Saponins have been identified as the primary toxic substance in snakeweed, but the plant also contains numerous other compounds (essential oils, mono- and sesquiterpenes, flavonals, tannins, alkaloids, etc.) that contribute to their toxicity. Kingsburg (1964) summarized the poisoning symptoms reported by various investigators (Mathews 1936, Dollahite and. Anthony 1957, Dollahite and Allen 1959) and concluded in acute cases death occurs, but the major threat from snakeweed consumption is abortion. Other toxic effects include premature calves and decreased feed intake and body weight gains. Losses caused by abortion and birth related abnormalities in cattle, sheep, and goats from snakeweed are poorly documented and sporadic (Norris and Valentine 1957, Martinez et al. 1993).

\footnotetext{
${ }^{\mathrm{I}}$ This paper was compiled in part, for the symposium: Do most livestock losses from poisonous plants result from 'poor' management? This symposium was held in conjunction with the Society for Range Management meeting in Boise, Ida. 13-18 Feb. 2000.
}

Livestock displaying symptoms from snakeweed poisoning under rangeland conditions are likely to have a decreased nutrient status and body condition accelerated by malnutrition. Healthy grazing animals are not likely to eat the plant unless other forage is extremely scarce (Mathews 1936). Thus intuitively, rangelands with poor forage conditions (or range condition) are areas of concern but can be remedied in the short term with nutrient supplementation (Strickland et al. 1998) and in the long term by increasing forage availability.

\section{Toxicity Studies at New Mexico State University (NMSU) from 1980 to 2000}

Several studies have confirmed snakeweed toxicity under confined feeding conditions but, to our knowledge, no research has been able to demonstrate snakeweed poisoning under actual rangeland grazing experiments. Beck et al. (1999) grazed mature cows in various experiments on rangelands dominated by snakeweed on the Chihuahuan Desert Rangeland Research Center near Las Cruces, N.M. from 1992 to 1998 and never witnessed animals eating the plant. Similarly, grazing trials with goats in the same area from 1989 to 1993 reported little use of snakeweed except when other herbage was grazed out (Beck et al. 1996). According to Beck et al. (1996), heavy goat stocking for 5 summer seasons resulted in no grazing damage to snakeweed because the animals removed so little plant material. Cox (2000) examined cattle grazing paddocks with varying snakeweed densities on four New Mexico ranches and after conducting microhistological evaluations reported snakeweed present in only 1 of 337 fecal samples analyzed. Cox also followed individual animals placed in 1 ha sized paddocks with very high snakeweed densities (between 33 to $70 \%$ vegetation composition) and through bite count observations noted that snakeweed was usually not grazed but that certain animals ingested between 0.4 to $6 \%$ of their diet. Cox did not observe any visible toxicity symptoms from animals that ate the plant.

Most NMSU investigations studying snakeweed poisoning effects on animals have relied on findings from confined feeding trials (Table 1). Experiments usually have included field harvested snakeweed that is dried and ground in the lab and then added in graded dosages with hay, alfalfa, corn or soybean meal to pro- duce isocaloric and isonitrogenous diets. Smith et al. (1991) examined the response of rats to increasing levels of snakeweed in the diet ranging from 0 to $25 \%$. These authors found that pregnancy rates decreased when dietary snakeweed exceeded $12.5 \%$. They also reported that reproductive functions were impaired before evidence of liver or kidney damage. In the Smith et al. (1991) study, they found that after 35 days of snakeweed feeding that rats exhibited evidence of liver and biliary toxicosis indicated by elevated alkaline phosphates, gamma-glutamyltranspeptidase, and alanine aminotransferase. When pregnant rats were fed snakeweed at levels above $10 \%$ in the diet, embryonic mortality and early fetal death was noted. Also, blood urea nitrogen and creatinine concentrations were elevated suggesting some damage to the kidneys. In the aforementioned experiments by Smith et al. (1991), snakeweed was harvested by hand clipping the new growth portion ( 5 to $10 \mathrm{~cm}$ ) of the plant during pre-bloom.

Oetting et al. (1990) fed snakeweed to ewes at levels ranging from 0 to $25 \%$ of diets. With alfalfa hay as the base feed mixed with $25 \%$ snakeweed, ewes easily consumed the diet. Ewes fed 12.5 and $25 \%$ snakeweed with alfalfa hay experienced longer estrous cycles and higher serum progesterone concentrations than ewes fed less snakeweed. When the base feed included blue grama hay mixed with snakeweed, the ewes were unwilling to eat diets containing more than $10 \%$ snakeweed. Ewes that ate the blue grama hay base diet with $10 \%$ snakeweed experienced mild liver and kidney toxicosis and had significantly lower estrual activity than animals fed $0 \%$ snakeweed diets.

Working with cannulated sheep, Edrington et al. (1991) compared diets with 0,50 or $100 \%$ fresh snakeweed placed directly in the rumen. Blood samples taken on these animals showed that the 50 and $100 \%$ snakeweed diets elevated levels of gamma-glutamyltranspeptidase, aspartate amino-transferase, and alkaline phosphates, and that unconjugated bilirubin increased in the serum. These symptoms indicate that hepato-toxicity was occurring with the ewes fed snakeweed. Also, rumen function was affected as indicated by a shift from high acetate to more propionate production in the rumen. These data agreed with a similar study reported by Hall et al. (1991).

Williams et al. (1993) conducted an experiment using 56 beef heifers fed either 
Table 1. Feeding studies investigating snakeweed toxicosis with various herbivores from 1986 to the present at New Mexico State University.

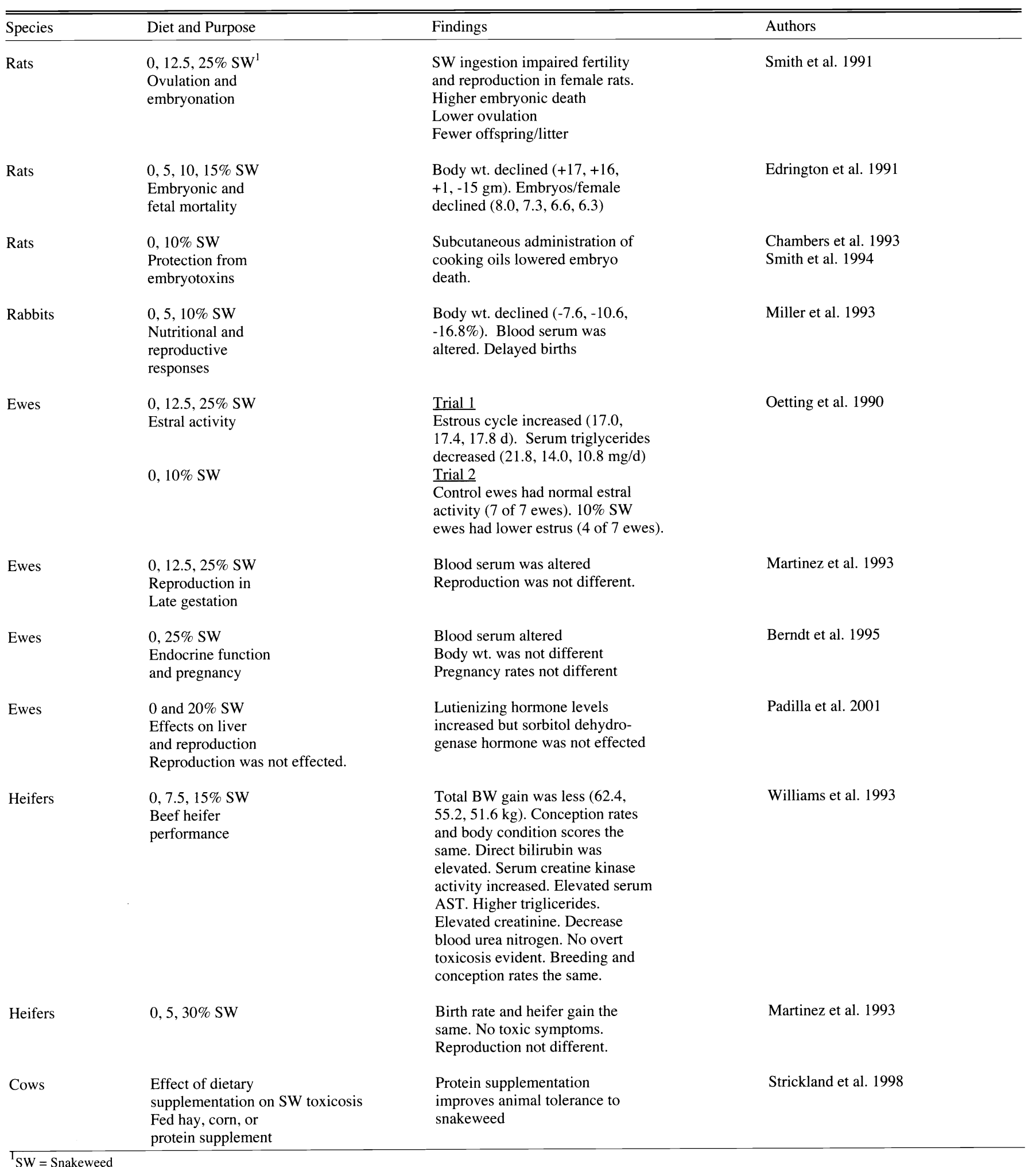

alfalfa hay (controls) or diets mixed with alfalfa plus 7.5 and $15 \%$ snakeweed. Forage intake was restricted to $7.7 \mathrm{~kg}$ daily. Entire snakeweed plants had earlier been mechanically harvested, air dried, chopped and mixed with the alfalfa. Heifers received their respective diets for 98 days. After 42 days of feeding, heifers were estrually synchronized and artificially inseminated after which bulls were placed with the heifers and rotated through pens daily. Heifers receiving the snakeweed diet gained less weight than the controls throughout the trial, however, conception rates and body condition scores 
were not different. Serum chemistries indicated a mild hepato-toxicosis. In a similar study, Martinez et al. (1993) assigned groups of 24 pregnant heifers (240 days pregnant) to 0,15 or $30 \%$ whole plant snakeweed and chopped alfalfa hay diets. No abortions were recorded for any treatment suggesting that heifers can tolerate 15 to $30 \%$ snakeweed when fed a base diet of alfalfa. Martinez et al. (1993) conducted another study with ewes in late gestation feeding either alfalfa or a $25 \%$ snakeweed-alfalfa based diet. As with the heifers, no abortions were noted in the ewes and lamb birth weights were unaffected. It is important to note that both Williams et al. (1993) and Martinez et al. (1993) fed whole plant snakeweed rather than fresh or new growth clippings. Oetting et al. (1990) and Edrington et al. (1991) indicated that fresh leaf material is likely to be more toxic than whole plant snakeweed samples.

Berndt et al. (1995) conducted experiments to determine if new-growth snakeweed placed directly into ruminally cannulated ewes would alter the sensitivity of the pituitary gland to gonadotropin-releasing hormones $(\mathrm{GnRH})$. In their first experiment, 8 ewes received no snakeweed or $25 \%$ snakeweed as a portion of a blue grama grass hay diet. After 35 days on the diets, ewes were administered $10 \mu \mathrm{g}$ of $\mathrm{GnRH}$ and blood was collected at 15 minute intervals for 5 hours. After blood sampling, ewes were joined with fertile rams. The luteinizing hormone response to GnRH was significantly higher in ewes receiving $25 \%$ snakeweed compared to animals eating only blue grama hay. Treatments continued for 68 days after which ewes were euthanized and pregnancy status was determined by examination of uterine tissue. Pregnancy rates were unaffected by snakeweed ingestion. In a second experiment by Berndt et al (1995) alfalfa hay was used instead of blue grama as the base diet. Ewes were fed below NRC (1985) requirements similar to the first experiment. After 29 days on 0 or $25 \%$ snakeweed diets, a GnRH challenge was conducted. Unlike the first experiment, no differences were found for luteinizing hormone response. The authors indicated that the nutritive quality differences between blue grama and alfalfa hay base feed diets was probably most responsible for the differences in pituitary response to GnRH shown in these 2 experiments.
Strickland et al. (1998) conducted experiments to determine if dietary supplementation could lower snakeweed toxicity effects on beef cows in poor body condition. Dietary treatments were no snakeweed and $10 \%$ snakeweed mixed with $628 \mathrm{~g}$ cracked corn and $800 \mathrm{~g}$ of a $42 \%$ crude protein supplement provided daily. Dry matter intake was limited to $1.3 \%$ of body weight. Bromosulphothalein (BSP) clearance tests were conducted to determine the liver's ability to catalyze phase II biotransformations. Snakeweed consumption did not influence the elimination of BSP but the exchange rate from the blood to other tissues was accelerated. Supplementation with corn or protein increased the clearance rate of BSP. This suggests that if the nutrient status in an animal is improved, then there may be a greater tolerance to toxicants metabolized by phase II biotransformations. In unpublished data from this experiment, serum progesterone and estrogen concentrations did not differ among the 0 and $10 \%$ snakeweed diets or supplementation types. Also, ovarian follicular development was not affected by snakeweed or supplements.

Subsequently, 2 additional trials have been conducted at NMSU to determine the effects of snakeweed on biotransformation mechanism in sheep. Padilla et al. (2001) compared pair-fed wethers having diets containing $0 \%$ or $20 \%$ snakeweed on a dry matter basis. Caffiene and BSP clearance were measured to evaluate the ewes ability to eliminate xenobiotics. Caffiene clearance was not different between treatments but wethers consuming snakeweed exhibited reduced $(\mathrm{P}<0.05)$ BSP clearance. In a second experiment, Padilla et al. assigned 10 ewes to either a $0 \%$ or $20 \%$ snakeweed diet and animals were again pair-fed to equalize intake. Blood samples were collected to measure luteinizing hormone (LH) and sorbitol dehydrogenase (SDH) which is a liver specific enzyme. Animals fed the snakeweed diet had higher baseline concentrations of LH but SDH concentrations were not different from the control diets. The authors suggested that the elevated $\mathrm{LH}$ in ewes consuming snakeweed was due to a high lipid content in the plant. Ewes were exposed to fertile rams and pregnancy rates in these experiments were similar for both diets.

Current research at NMSU is evaluating different extractions of snakeweed to identify specific toxicants. Also, experiments are being conducted to determine the rela- tionship between liver damage and reproductive problems. A major question that remains unanswered related to snakeweed toxicity is a precise definition of its poisonous principal. Without this knowledge it is difficult to determine how snakeweed ingestion influences mechanisms of action within the animal (Strickland et al. 1998).

\section{Snakeweed Impact on Animal and Forage Loss}

Direct animal health problems from snakeweed consumption, such as abortion and death, were recognized as an important range management concern in the 1920's and 1930's (Mathews 1936, Smith et al. 1991). How widespread the problem is today is not known but some estimates are available. Based on a survey of county agents in west Texas, snakeweed poisoning causes $1 \%$ annual death loss in cattle and a $2.9 \%$ annual abortion rate (Torell et al. 1988 from McGinty and Welch 1987). Sheep and goat death losses were an estimated $0.7 \%$ and $0.4 \%$, respectively, whereas abortion losses were $1.3 \%$ and $0.7 \%$, respectively. As is the case with many poisonous plants, however, general estimates of loss are often not very meaningful because it is specific damage to a particular animal, herd or ranch operation that is most important. Thus most researchers agree that snakeweed related losses, such as abortion and birth-related abnormalities in cattle, sheep and goats are sporadic and vary widely by location, season, climate, soil, and range conditions (Norris and Valentine 1957, Martinez et al. 1993, Williams et al. 1993).

Indirect animal health problems resulting from emaciation, malnutrition, and lack of gain on rangeland densely infested with snakeweed is a greater economic burden to livestock producers than snakeweed poisoning (Torell et al. 1988). Grass production can be decreased by $90 \%$ or more in extremely dense snakeweed stands (McDaniel et al. 1982). Lack of suitable forage in the presence of snakeweed necessitates livestock producers to either provide a supplement, drastically reduce stocking rates, and/or remove the weed. Whatever alternative is chosen, the cost to producers is high. Economic losses from snakeweed varies depending on beef prices and production cost, but on the 10 million ha of rangeland in the western United States infested with snakeweed, losses are substantial (McDaniel and Torell 1987). 


\section{Snakeweed/Grass Interaction}

The snakeweed-overstory and grassunderstory biomass relationship has been expressed using sigmoidal growth and negative exponential equations (McDaniel et al. 1993). The downward sloping convex shape of an exponential equation implies that grass production is retarded with even a minor snakeweed presence, thus for management purposes control strategies that maximize snakeweed removal are likely to be most economically efficient (Tanaka and Workman 1988). The sigmoid shape (Fig. 1) implies that a minor amount of snakeweed does not affect grass biomass but that once a threshold is reached then grass biomass is drastically reduced, i.e. in a manner similar to that estimated by a negative exponential equation.

Having an appreciation of the snakeweed-overstory and grass-understory relationship has practical management implications when trying to decide whether to use prescribed fire or a herbicide to control snakeweed (Fig. 1). For example, in areas with a moderate to dense amount of snakeweed (areas with $>300 \mathrm{~kg} / \mathrm{ha}$ snakeweed), burning is usually impractical because fine fuels are often insufficient in quantity and uniformity to carry a fire (McDaniel et al. 1997). Rangelands with high amounts of snakeweed are generally better managed with an aerial herbicide application than fire. Where light amounts of snakeweed and sufficient grass occur $(<$ $300 \mathrm{~kg} / \mathrm{ha}$ snakeweed and $>500 \mathrm{~kg} / \mathrm{ha}$ of grass), then prescribed fire is often a better management choice than herbicide control because it is less costly. An expectation after employing either control method is that a favorable grass response will offset treatment cost (Torell et al. 1988).

Rangelands dominated by snakeweed are often perceived as being in poor range condition because grass growth languishes beneath dense canopies. However, caution must be exercised to distinguish between what might be poor forage condition as opposed to poor ecological (range) condition. Rangelands with dense snakeweed may or may not be in poor range condition, but they are nearly always in poor forage condition. To further illustrate the importance of understanding the overstory-understory relationship, Figure 2 shows a 20 year comparison of snakeweed and grass biomass taken from undisturbed research plots near Vaughn and Roswell, New Mexico. A portion of this data, and the manner in which it was collected has

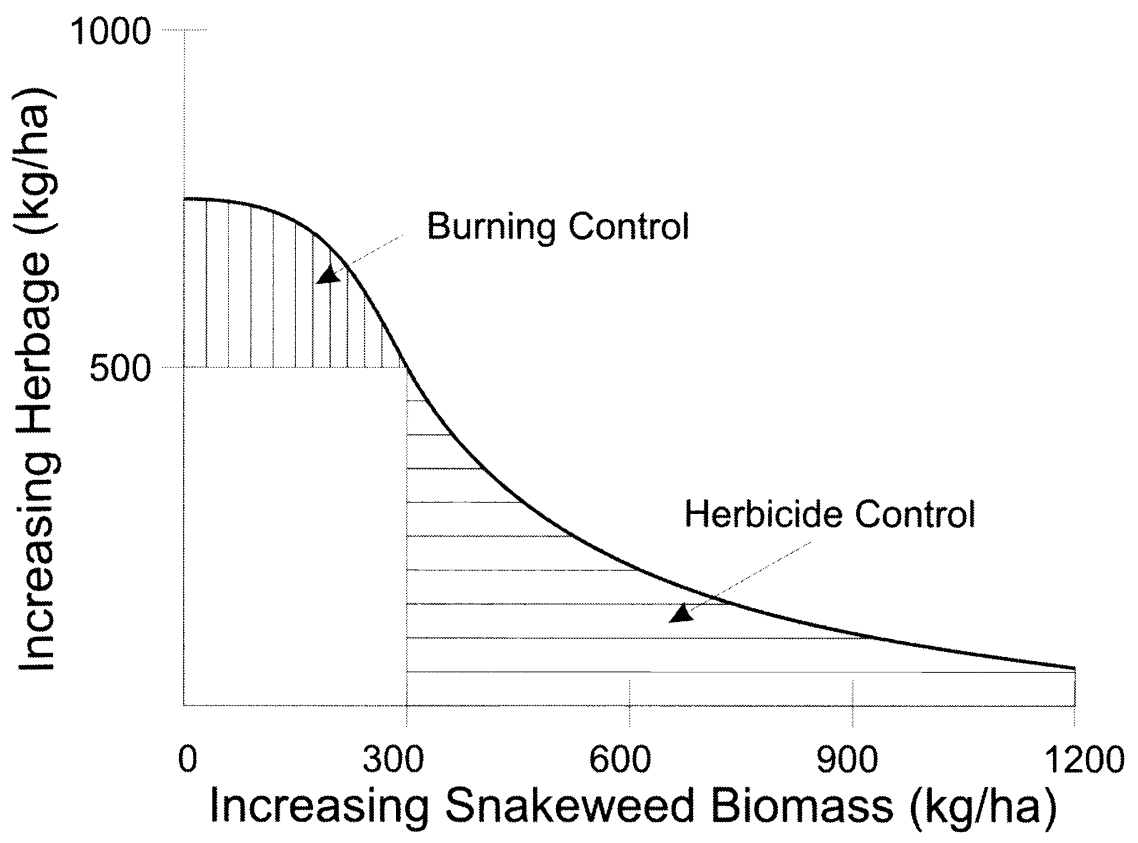

Fig. 1. Sigmoid curve illustrating the snakeweed-overstory and grass-understory relationship and areas where burning or herbicide control become most practical.

been described in part elsewhere (McDaniel 1989, McDaniel and Duncan 1987). At these locations, data were acquired from replicated untreated plots ( 0.1 ha in size) placed in pastures that had a high initial density of snakeweed. Blue grama was the principal associated grass. Over the 20-year study period landownership did not change and, in general, the ranchers employed consistent grazing management practices through time. Figure 2 indicates that during years when snakeweed was highly dominant, such as in the early 1980's, grass growth was highly suppressed. Only after snakeweed naturally declined at these locations did grass yield increase. Typically, grass yield increases 4 to 6 fold after a dense snakeweed stand dies-out or when the weed is removed by herbicide spraying (McDaniel et al. 1982, McDaniel and Duncan 1987).

\section{How Snakeweeds Longevity Effects Management Decisions}

Snakeweed populations have been described in the literature as cyclic through time (Jameson 1970). That is, propagation occurs under favorable environmental conditions and plants survive until conditions become unfavorable, then they die. The term cyclic implies a regular and repeated life history pattern that is expected to occur over many years. In actuality, the number of snakeweed plants and length of time they might survive in a given area is neither repeatable or predictable thus the term "cyclic" must be used in a restrictive sense when describing snakeweed populations. A 100-year record set from permanent quadrats placed on the Joronada Experimental Range in southern New Mexico indicated that the average life expectancy for snakeweed was about 4 years, but that some individual plants lived longer than 15 years (Dittberner 1971). There was no indication from the Joronada data set that the snakeweed population was predictably cyclic over time.

Environmental events that influence snakeweed seed production (Wood et al. 1997), trigger germination (Kruse 1979, Mayeux and Leotta 1981, Mayeux 1983), and affect survival (McDaniel 1989) are becoming better understood. Close study of seedling establishment suggests that the optimal environmental conditions necessary for propagation occur only once or twice a decade in the southwestern United States. Snakeweed seedlings have been noted after above-average winter precipitation in the Chihuahuan Desert of southern New Mexico (Barnett 1996, Beck et al. 1999), and with above-average spring precipitation on blue grama rangeland in central New Mexico (McDaniel et al. 2000). Die-offs from weather usually result from summer drought but insects and old age are also responsible for natural plant losses (Pieper and Mc Daniel 1989). 

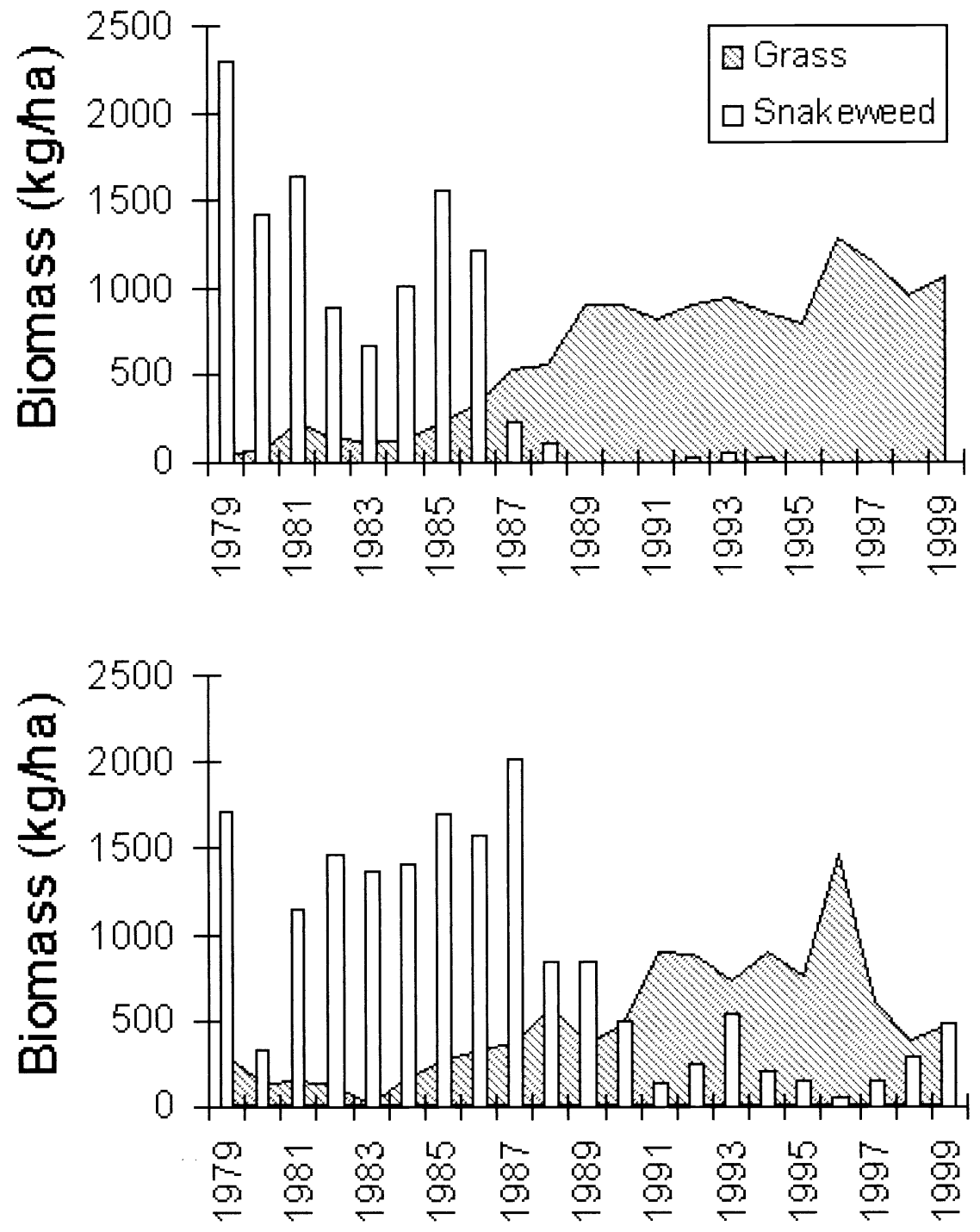

Fig. 2. Snakeweed biomass (bars) and grass biomass (shaded area) on native rangeland near Roswell (top) and Vaughn (bottom), New Mexico 1979 to 1999.

Because some describe snakeweed as a short-lived perennial (Lane 1985, Solbrig $1960,1964)$, it seems logical to assume that fecundity and mortality rates may be predictable across a regional population. However, the snakeweed cyclic pattern is rarely identical from 1 ecological site to another (Mc Daniel 1989). Consider again Figure 2 giving the 20 year snakeweed biomass pattern near Vaughn and Roswell, New Mexico. These sites are within a 50 mile radius of each other and the snakeweed pattern at each shares certain similarities but also differences. In 1980, the region experienced severe summer drought and there was a significant die-off of mature snakeweed plants at Vaughn, but plants survived at Roswell. In 1981, brings into question the difficulty and perhaps value of trying to predict snakeweed's cyclic pattern across broad regional areas.

\section{Snakeweed Management}

The decision as what to do when snakeweed is a dominant plant involves basically 2 choices. One choice is to leave it alone and to manage around the plant. The hope is that drought, insects, or old age will cause it to die-out and that snakeweed propagation will not soon follow. The second choice is to intervene, using herbicide, fire or mechanical control to eliminate the plant. Consider Figure 2 again to illustrate how either choice can result in an economic hardship to a ranching operation. At Roswell the decision not to control snakeweed in the early 1980s meant the owner had to endure grass growth that was highly suppressed under a generation of snakeweed that lasted for 8 years (1981 to 1988). Fortunately, at this location, when mature snakeweed plants died new seedlings did not follow and this allowed grasses to recover over the next 11 years (1989 to 1999). If the Roswell owner had decided to control snakeweed shortly after plants established in 1981, then the treatment would probably have been economically beneficial. However, if the owner had waited and not controlled snakeweed until just before it naturally died (i.e. 1986-87), then little benefit would have been derived in terms of increased forage. According to Torell et al. 1988, an area where snakeweed is controlled by herbicide spraying must remain snakeweed free for a minimum of 4 years to be economically effective. In contrast, at Vaughn, snakeweed has persisted from 1981 to the present, thus the owner has experienced forage suppression for 20 years. If the Vaughn owner had decided to control snakeweed shortly after the new snakeweed generation established in 1981 then the benefits from eliminating the weed would have been long lasting. This timing is verified from herbicide control experiments conducted annually at the Vaughn location from 1979 to 1987 (Table 2; McDaniel 1987). In these experiments, the herbicide picloram was applied and usually provided $95 \%$ or better snakeweed control as determined from evaluations made 12 months after treatment. Sprays applied in 1979 and 1980 killed mature snakeweed but these treatments were short-lived because of the 1981 germination event that 
Table 2. Snakeweed control 12 months after spraying with picloram ${ }^{1}$, and subsequent evaluations made in 1988 and 1999 near Vaughn, N.M.

\begin{tabular}{lccc}
\hline \hline $\begin{array}{l}\text { Year } \\
\text { Sprayed }\end{array}$ & $\begin{array}{c}1^{\text {st }} \text { yr after } \\
\text { treatment }\end{array}$ & 1988 & 1999 \\
\hline & $----\%$ & Snakeweed Control----- \\
1979 & 98 & 25 & 0 \\
1980 & 95 & 3 & 0 \\
$1981^{2}$ & -- & -- & -- \\
1982 & 83 & 83 & 75 \\
1983 & 100 & 100 & 100 \\
1984 & 99 & 99 & 99 \\
1985 & 99 & 99 & 100 \\
1986 & 100 & 99 & 100 \\
1987 & 100 & 100 & 100 \\
1988 & 100 & 100 & 100 \\
\hline
\end{tabular}

${ }^{1}$ Picloram applied at $0.56 \mathrm{~kg} / \mathrm{ha}$ in 1979,1980 , and 1982 ; applied at $0.28 \mathrm{~kg} / \mathrm{ha}$ in 1983 to 1988 .

${ }^{2}$ No treatments made in 1981 .

resulted in the treated areas to appear similar to nonsprayed rangeland within a few years of treatment. However, areas sprayed at the Vaughn location in 1982 or later have remained essentially snakeweed free for the next 18 years.

Eliminating snakeweed by herbicide or fire control can result in an increase in rangeland carrying capacity and can also reduce livestock losses caused by poisoning and malnourishment. McDaniel and Duncan (1987) reported that with $90 \%$ or greater snakeweed control with a herbicide, the carrying capacity at Vaughn changed from $1 \mathrm{AU} / 62$ ha to $1 \mathrm{AU} / 20$ ha, and at Roswell the change was from 1 $\mathrm{AU} / 88$ ha to $1 \mathrm{AU} / 7$ ha. With commercial aerial application cost of $\$ 22$ per ha to spray picloram at a $0.28 \mathrm{~kg} / \mathrm{ha}$ rate, the buyer needs at least 4 years of benefit to justify the expense (Torell et al. 1988). Cost related to prescribed fire depends on the size of the area to be burned and available labor and logistical support. Typically, areas to be burned must be deferred at least 2 growing seasons: one season to build up adequate fine-fuel loads, and a second season for grass recovery (McDaniel et al. 1997). Combined, chemical control may be viewed as a reclamation tool to reduce high densities of snakeweed, whereas burning control is a tool for maintaining non-economic populations of snakeweed (Sterling et al. 1999).

\section{Literature Cited}

Beck, R. F., R. P. McNeely, and S. J. Muir. 1996. Effects of goats and drought on snakeweed. Abstract in $49^{\text {th }}$ Ann. Meeting of Soc. for Range Mangement pp. 7. Feb. 10-15, 1996.

Beck, R. F., M. Nsinamwa, R. Santos, and R. D. Pieper. 1999. Dynamics of Gutierrezia sarothrae with drought and grazing. In: Eldridge and Freudenberger. pp. 502-504. Proc. of the VI Internat.. Range Congress, Vol. 1, Townsville, Australia.

Berndt, M. Y., T. T. Ross, and D. E. Hawkins. 1995. The effects of snakeweed (Gutierrezia microcephala and G. sarothrae) on endocrine function and establishment of pregnancy in ewes. In: Proc. West. Sect. Amer. Soc. Anim. Sci. 46:69-72.

Barnett, B. L. 1996. Influence of winter precipitation on broom snakeweed establishment in the Chihuahuan Desert. M.S. Thesis. New Mexico State Univ., Las Cruces, N.M.

Cox, S. H. 2000. Snakeweed (Gutierrezia spp.) consumption by grazing beef cattle. M. S. Thesis. New Mexico State University, Las Cruces, N.M.

Chambers, S.W., G.S. Smith, M. S. Stavanja, E. C. Staley, J. P. Thilstead, and D. M. Hallford. 1993. Safflower oil protects rats from embryotoxins of ingested snakeweed foliage. Proc. West. Sec. Amer. Soc. of Anim. Sci. 44:

Dittberner, P. L. 1971. A demographic study of some semi-desert grassland plants. M. S. Thesis, New Mexico State University, Las Cruces, N.M.

Dollahite, J. W. and T. J. Allen. 1959. Feeding perennial broomweed to cattle, swine, sheep, goats, rabbits, guinea pig, and chickens. Texas Agr. Exp. Sta. PR-2105. College Station, Tex.

Dollahite, J. W. and W. V. Anthony. 1957. Poisoning of cattle with Gutierrezia microcephala, a perennial broomweed. J. Amer. Vet. Med. Assoc. 130:525-30.

Edrington, G. S. Smith, M. D. Sanford, J. Medrano, T. T. Ross, and J. C. Thilsted. 1991. Ingested snakeweed foliage related to embryonic and fetal mortality of albino rats. In: Proc. West. Sec., Amer. Soc. Anim. Sci. 42:12-14.

Foster, D. E., D. N. Meckert, and C. J. DeLoach. 1981. Insects associated with broom snakeweed and threadleaf snakeweed in west Texas and eastern New Mexico. J. Range Manage. 34:446-454.

Hall, L.E., M.L. Galyean, and T.T. Ross. 1991. Effect of increasing level of snakeweed on digestibility of alfalfa and grass hay in vitro. Proc., West. Sec., Amer. Soc. Anim. Sci. 42:292.

Jameson, D. A. 1970. Value of broom snakeweed as a range condition indicator. J. Range Manage. 23:302-304.

Kingsbury, J. M. 1964. Poisonous plants of the United States and Canada. Prentice-hall, Inc. Englewood Cliffs, New Jersey, pp. 406-408.
Kruse, W. H. 1979. Temperature and moisture stress affect germination of Gutierrezia sarothrae. J. Range Manage. 23:143-45.

Lane, M. A. 1985. Taxonomy of Gutierrezia (Composiate: Astereae) in North America. Syst. Bot. 10:7-28.

Martinez, J. H., T. T. Ross, K. A. Becker, J. L. Williams, D. Campos, and G. S. Smith. 1993. Snakeweed toxicosis in late gestation ewes and heifers. In: Sterling, T. M. and D. C. Thompson (eds.).pp. 48-49. Snakeweed Research: Updates and Highlights. New Mexico Agric. Exp. Stn. Res. Report \#674.

Mathews, F. P. 1936. The toxicity of broomweed (Gutierrezia microcephala) for sheep, cattle, and goats. J. Amer. Vet. Med. Assoc. 88:56-61.

Mayeux, H. S., Jr. 1983. Effects of soil texture and seed placement on the emergence of four subshrubs. Weed Sci. 31:380-84.

Mayeux, H. S. and L. Leotta. 1981. Germination of broom snakeweed and threadleaf snakeweed. Weed Sci. 29:530-534.

McDaniel, K. C. 1989. Use of herbicides in snakeweed management.In: Snakeweed: Problems and Perspectives. E. W. Huddleston and R. D. Pieper (eds.). pp. 85-99. New Mexico Agr. Exp. Sta. Bull. 751.

McDaniel, K. C. and K. W. Duncan. 1987. Broom snakeweed (Gutierrezia sarothrae) control with picloram and metsulfuron. Weed Sci. 35:837-41.

McDaniel, K. C. and L. A. Torell. 1987. Ecology and management of broom snakeweed. In: Integrated pest management on rangeland, a shortgrass prairie perspective. J. L. Capinera (ed.). Westview Press. Boulder, Colo., 101-15.

McDaniel, K. C., D. B. Carroll, and C. R. Hart. (2000). Broom snakeweed establishment on blue grama grasslands after fire and herbicide treatments. J. Range Manage 53:239-245.

McDaniel, K. C., C. Hart, and D. B. Carroll. 1997. Broom snakeweed control with fire on New Mexico blue grama rangeland. J. Range Manage. 50:652-59.

McDaniel, K. C., R. D. Pieper, and G. B. Donart. 1982. Grass response following thinning of broom snakeweed. J. Range Manage. 35:142-45.

McDaniel, K. C., L. A. Torell, and J. W. Bain. 1993. Overstory-understory relationships for broom snakeweed-blue grama grasslands. J. Range Manage. 46:506-11.

McGinty, A. and T. G. Welch. 1987. Perennial broomweed and Texas ranching. Rangelands 9:246-249.

Miller, R. J., G. S. Smith, and R. L. Byford. 1993. Nutritional, toxicological, and reproductive responses in female domestic rabbits fed snakeweed foliage. In: Proc. West. Sect. Amer. Soc. Anim. Sci. 44:122-125.

Norris, J. J. and K. A. Valentine. 1957. Principal livestock-poisoning plants. New Mexico A\&M College, Agr. Extension Serv. Cir. 274. 
NRC. 1985. Nutrient requirements of sheep $\left(6^{\text {th }}\right.$ edition). National Academy Press, Washington D.C.

Oetting, B. C., T. T. Ross, K. Walraven, P. Kloppenburg, G. S. Smith, and D. M. Hallford. 1990. Effects of ingested snakeweed herbage on actual activity, blood progesterone, and serum clinical profiler of finewool ewes. In: Proc. West. Sect. Amer. Soc. Anim. Sci. 41:23-26.

Padilla, D. J., T. T. Ross, J. P. Strickland, D. M. Hallford, M. W. Salisbury, and J. L. Bollinger. 2001. Effects of snakeweed (Gutierrezia spp.) ingestion on reproduction and liver function in sheep. Proc., West. Sec., Amer. Soc. Anim. Sci. 52:45-49.

Pieper, R. D. 1989. Broom snakewood content of herbivore diets. In: Snakeweed: Problems and Perspectives. E. W. Huddleston and R. D. Pieper (eds.). pp. 203-10.New Mexico Agr. Exp. Sta. Bull. 751.

Pieper, R. D. and K. C. McDaniel. 1989. Ecology and management of broom snakeweed. In: Snakeweed: Problems and Perspectives. E. W. Huddleston and R. D. Pieper (eds.). New Mexico Agr. Exp. Sta. Bull. 751, 1-12.

Richman, D. B. and D. C. Thompson. 1995. Insect associations with woody snakeweeds in New Mexico, Texas, and Arizona. In: Papers from the Fourth Symposium on Resources of the Chihuahuan Desert Region. Chihuahuan Desert Res. Inst., Alpine, Tex..
Smith, G.S. and G.I. Flores-Rodriguez. 1989. Toxicity of snakeweeds. In: Huddleston and Pieper. pp. 211-219. Snakeweed: Problems and Perspectives. NMSU Agr. Exp. Bull. 751 .

Smith, G. S., T. T. Ross, G. S. FloresRodriguez, B. C. Oetting, and T. S. Edrington. 1991. Toxicology of snakeweeds, Gutierrezia microcephala and $G$. sarothrae. In: James, Evans, Ralphs, and Child. pp. 236-246. Noxious Range Weeds. Westview Press, Boulder, Colo..

Smith, G. S., T. T. Ross, D. M. Hallford, J. P. Thisted, E. C. Stales, J. A. Greenberg, and R. J. Miller. 1994. Toxicology of snakeweeds (Gutierrezia sarothrae and G. microcephala). Proc. West. Sec. Anim. Soc. of Anim. Sci. 45:98-102.

Solbrig, O. T. 1960. Cytotazonomic and evolutionary studies in the North American species of Gutierrezia (Composiate). Controb. Gray herb. 188:1-61.

Solbrig, O. T. 1964. Intraspecific variation in the Gutierrezia sarothrae complex (Compositate-Asteraceae). Contrib. Gray Herb. 193:67-115.

Sterling, T. M.., D. C. Thompson, and K. C. McDaniel. 1999. Snakeweeds. In: Biology and Management of Noxious Rangeland Weeds. R. L. Sheley and J. K. Petroff (eds). Oregon State University Press, Corvallis, Ore.
Strickland, J. R., L. F. Gulimo-Klein, T. T. Ross, S. Slate, M. K. Petersen, T. May, and J. B. Taylor. 1998. Effects of nutrient supplementation in beef cows of poor body condition fed snakeweed (Gutierrezia spp.). Vet. and Hum. Tox. 40:278-284.

Tanaka, J. A. and J. P. Workman. 1988. Economic optimum big sagebrush control for increasing crested wheatgrass production. J. Range Manage. 41:172-178.

Thompson, D. C., K. C. McDaniel, L. A. Torell, and D. B. Richman. 1995. Damage potential of Hesperotettix viridis (Orthoptera Accidental) on a rangeweed, Gutierrezia sarothrae. Environ. Ento. 24:1315-1321.

Torell, L.A., H. W. Gordon, K. C. McDaniel, and A. McGinty. 1988. Economic impact of perennial snakeweed infestations. In: The ecology and economic impact of poisonous plants on livestock production. James, L. F., M. H. Ralphs, and D. B. Nielson (eds.) pp., 57-69. Westview Press. Boulder, Colo.

Williams, J. L., D. Campos, T. T. Ross, G. S. Smith, J. M. Martinez, and K. A. Becker. 1993. Heifer reproduction is not impaired by snakeweed consumption. In: Sterling, T. M. and D. C. Thompson (eds.). Snakeweed Research: Updates and Highlights. New Mexico Agr. Exp. Sta. Res. Report 674: 46-47.

Wood, B. L., K. C. McDaniel, and D. Clason. 1997. Broom snakeweed (Gutierrezia sarothrae) dispersal, viability, and germination. Weed Sci. 45:77-84. 